\title{
ULTRA-HIGH STRENGTH STEEL FIBER REINFORCED CONCRETE FOR STRENGTHENING OF RC FRAMES
}

\author{
Yung-Chih Wang \\ Associate Professor, Department of Civil Engineering, National Central University, Jhongli, Taoyuan, 32001, Taiwan., \\ wangyc@cc.ncu.edu.tw \\ Ming-Gin Lee \\ Associate Professor, Department of Construction Engineering, Chaoyang University of Technology, Taichung County, \\ 413, Taiwan.
}

Follow this and additional works at: https://jmstt.ntou.edu.tw/journal

Part of the Civil and Environmental Engineering Commons

\section{Recommended Citation}

Wang, Yung-Chih and Lee, Ming-Gin (2007) "ULTRA-HIGH STRENGTH STEEL FIBER REINFORCED CONCRETE FOR STRENGTHENING OF RC FRAMES," Journal of Marine Science and Technology. Vol. 15: Iss. 3, Article 6.

DOI: $10.51400 / 2709-6998.2394$

Available at: https://jmstt.ntou.edu.tw/journal/vol15/iss3/6

This Research Article is brought to you for free and open access by Journal of Marine Science and Technology. It has been accepted for inclusion in Journal of Marine Science and Technology by an authorized editor of Journal of Marine Science and Technology. 


\section{ULTRA-HIGH STRENGTH STEEL FIBER REINFORCED CONCRETE FOR}

STRENGTHENING OF RC FRAMES

Acknowledgements

The authors would like to thank the National Science Council of Taiwan for the financial support under the grant NSC 93-2211-E-008-019. 


\title{
ULTRA-HIGH STRENGTH STEEL FIBER REINFORCED CONCRETE FOR STRENGTHENING OF RC FRAMES
}

\author{
Yung-Chih Wang* and Ming-Gin Lee**
}

Key words: ultra-high strength fiber reinforced concrete (UFC), strengthening, beam-column joint, shear resistance.

\begin{abstract}
Reinforced concrete (RC) structure strengthened with ultra-high steel fiber reinforced concrete (UFC) is introduced in the study. Interior RC beam-column joint sub-assemblages strengthened by means of joint replacement with UFC are tested cyclically to observe their seismic performance. Prior to frame testing, UFC mechanical properties, for example the compressive, flexural, rebar bonding, and slant shear strengths, and durability are examined and discussed. The material test results indicate that the UFC displays excellent performance in terms of mechanical and durable behavior. The frame test results show that the UFC-replaced joint frame behaves very well in seismic resistance. Its performance is even much better than the frame strengthened with RC jacketing as normally seen in the traditional retrofit schemes.
\end{abstract}

\section{INTRODUCTION}

Ultra-High Strength Steel Fiber-Reinforced Concrete (UFC) is an important recently developed type of construction material. This material has a very efficient high-tech cement-based matrix and a high fiber content, which make it both extremely strong and very durable. It is not often used in real structures however, mainly because new design concepts are needed before it can be successfully and cost-effectively applied $[4,5]$.

Selecting new materials for concrete structures requires an understanding of how the material behaves in both the uncured and cured states, given the anticipated service and exposure conditions. One of the greatest challenges for the successful performance of new materials is to control their dimensional behavior

Paper Submitted 04/11/07, Accepted 06/13/07. Author for Correspondence: Y.C.Wang. E-mail: wangyc@cc.ncu.edu.tw.

*Associate Professor, Department of Civil Engineering, National Central University, Jhongli, Taoyuan, 32001, Taiwan.

**Associate Professor, Department of Construction Engineering, Chaoyang University of Technology, Taichung County, 413, Taiwan. relative to the substrate. Relative dimensional changes can cause internal stress within the material as well as within the substrate. High internal stress may result in tension cracking, which can lead to loss of load-carrying capability and deterioration. Particular attention must be paid to select materials that properly address relative dimensional behavior so as to minimize these stresses [8].

UFC has remarkable flexural strength and very high ductility: the ductility is 250 times greater than that of conventional concrete [3, 7,9]. The material's extremely low porosity gives its low permeability and high durability, making it potentially suitable for retrofitting reinforced concrete structures or for use as a new construction material [2].

The goal of this paper is to describe the research done toward the realization of UFC as an option for normal concrete structures. Special concern will be given to beam-column joint frames in which the joints have been replaced by the UFC. It was reported that without any horizontal joint shear reinforcement, such as is typical of buildings constructed in Taiwan, the seismic response of these joints is very poor [10]. In addition to the above, this experimental study also focuses on evaluating the basic mechanical properties of UFC.

\section{EXPERIMENTAL PROGRAM}

\section{Mechanical testing of concrete materials}

Two cement-based materials, normal strength concrete (NC) and a high strength mortar (HSM), were compared with UFC during the experiments. The normal concrete (NC) had a compressive strength of 30 $\mathrm{MPa}$, with a slump of $150 \mathrm{~mm}$. The HSM used in the experiments consisted of a pre-packed repair mortar, containing $10 \%$ silica fume. Its compressive strength and low water cement ratio means that it had good durability. The UFC consisted of type II cement, silica fume, silica sand, quartz powder, steel fiber and a 
superplasticizer. The mix design of these materials is shown in Table 1.

The basic behavior of the three concrete materials during compressive strength, abrasion, slant shear, and steel bar pull-out testing was observed. Prior to testing two sizes of samples, $100 \mathrm{~mm}$ diameter $\times 200 \mathrm{~mm}$ high, and $50 \mathrm{~mm}$ in diameter $\times 100 \mathrm{~mm}$ high cylinders, and $100 \mathrm{~mm} \times 100 \mathrm{~mm} \times 350 \mathrm{~mm}$ prisms were prepared, as shown in Figure 1. The average value for three specimens was adopted to obtain the measured value.

A total of 24 concrete cylinders were used for the steel pull-out tests. A 280 Grade MPa \#3 reinforcing steel bar, $350 \mathrm{~mm}$ in length, was inserted in the center of concrete cylinders. Cylinders with no steel bar were tested according to the ASTM C131 Aggregate Abrasion Testing Procedure, using a Los Angeles Machine. Slant shear testing (ASTM C882) measured the shear strength between two substrates with an interface angle of inclination of $45^{\circ}$. The surface of the substrate concrete samples was prepared by sandblasting before placement.

The durability of the materials in an accelerated aging environment was evaluated by freeze-thaw cycle acceleration deterioration testing. The specimens were subjected to freeze-thaw cycles at a rate of one cycle per 185 minutes, in accordance with ASTM C666, with 90 minutes of freezing in cold air at $-18^{\circ} \mathrm{C}$ followed by 90 minutes of thawing in cool air at $+4.4^{\circ} \mathrm{C}$. Specimens that were not subjected to freeze-thaw cycling were stored in the materials testing laboratory. They were immersed in saturated lime water for 24 hours prior to testing. The specimens were subjected to $0,300,600$, or 1000 freeze-thaw cycles, with three specimens for each of these cycles. After the freeze-thaw test, the slant shear test and steel pull-out bond strength test were conducted to examine the durability.

\section{Strengthening of moment-resisting frames}

The three beam-column sub-assemblages used as moment-resisting frames in the test program are depicted in Figure 2. The as-built frame (JI) used for the strengthened units (JI-RC and JI-UFC) is typical of the old RC low-rise buildings constructed in Taiwan. The main deficiency was that there was no transverse reinforcement in the joint, as shown in Figure 2(a). This caused premature shear failure in the joint before failure in the column because joint was subjected to 4 to 6 times the column shear force, a common occurrence during seismic excitation [11].

Two types of retrofitting schemes, see Figures. 2 (b) and 2(c), were adopted to strengthen the as-built frame: RC jacketing with $100 \mathrm{~mm}$ thick NC (as displayed in JI-RC), and replacement of the joint core concrete with UFC (as seen in JI-UFC). This is the first time that UFC joint-replacement strengthening is con-

Table 1. Mix design of normal concrete (NC), high strength mortar (HSM), and ultra-high strength steel fiberreinforced concrete (UFC)

\begin{tabular}{cccccccccc}
\hline $\begin{array}{c}\text { Materials } \\
\left(\mathrm{kg} / \mathrm{m}^{3}\right)\end{array}$ & Cement & Stone & Sand & $\begin{array}{c}\text { Silica } \\
\text { sand }\end{array}$ & $\begin{array}{c}\text { Silica } \\
\text { fume }\end{array}$ & $\begin{array}{c}\text { Crushed } \\
\text { quartz }\end{array}$ & $\begin{array}{c}\text { Steel } \\
\text { fiber }\end{array}$ & $\begin{array}{c}\text { Super- } \\
\text { plasticizer }\end{array}$ & $\begin{array}{c}\text { Total } \\
\text { water }\end{array}$ \\
\hline NC & 342 & 926 & 785 & - & - & - & - & - & 222 \\
HSM & & & \multicolumn{2}{c}{ HSM $:$ Water $=1: 0.15$} \\
UFC & 720 & - & - & 900 & 216 & 252 & 40 & 71.3 & 133.7 \\
\hline
\end{tabular}

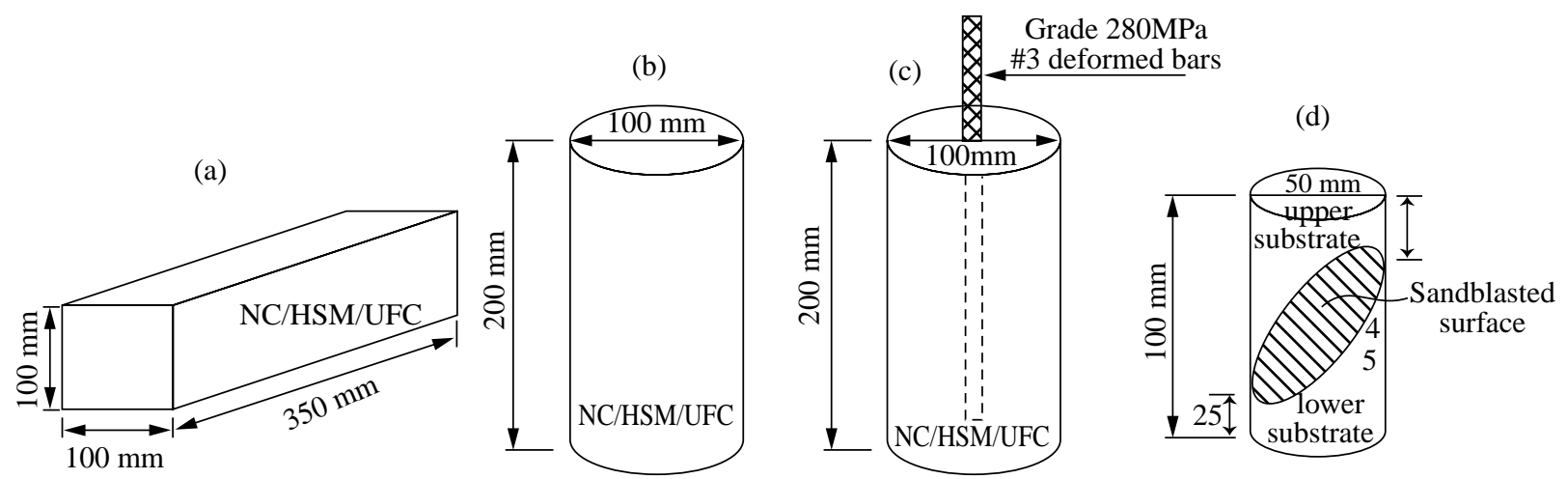

Fig. 1. Testing cylinders and prisms used for observing mechanical properties: (a) flexural tensile strength; (b) compressive strength and abrasion test; (c) rebar bond strength; (d) slant shear strength. 


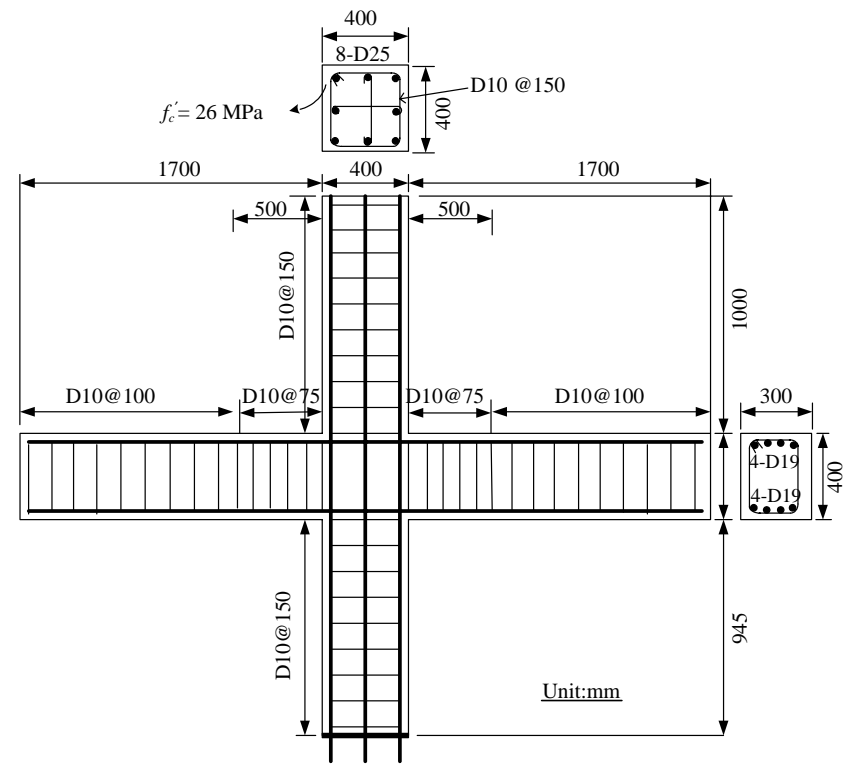

(a) Prototype unit, JI
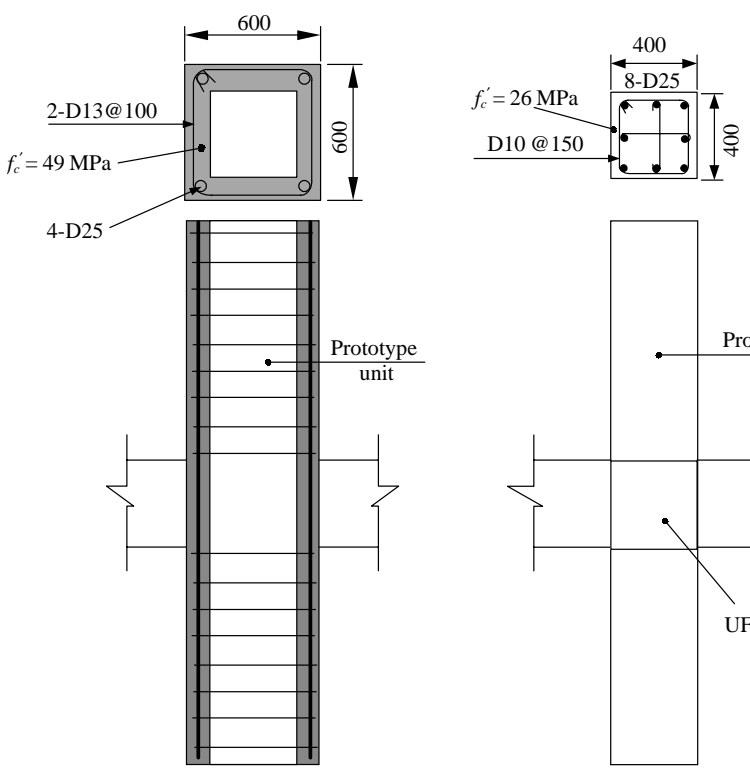

(b) RC jacketing unit, JI-RC

(c) UFC joint-replacement unit, JI-UFC

Fig. 2. Details of as-built and strengthened beam-column joints.

sidered as a new repair scheme, whereas RC jacketing is a widely adopted method for retrofitting sub-standard low-rise buildings. It was important to focus on observing the behavior of UFC when subjected to a very high shear stress field.

The material properties of the tested units are shown in Table 2. Testing frames were installed against strong floors and walls, so as to simulate partial moment-resisting frames subjected to earthquake loading; see Figure 3. Step-by-step quasi-static loading, representing earthquake loading, was applied to the top of
Table 2. Material properties for beam-column-joint test units

\begin{tabular}{ccccc}
\hline Materials & $\begin{array}{c}\text { Rebar Area } \\
\left(\mathrm{mm}^{2}\right)\end{array}$ & $\mathrm{f}_{\mathrm{c}}{ }_{\mathrm{c}}(\mathrm{MPa})$ & $\begin{array}{c}\mathrm{f}_{\mathrm{y}} \\
(\mathrm{MPa})\end{array}$ & $\begin{array}{c}\mathrm{f}_{\mathrm{u}} \\
(\mathrm{MPa})\end{array}$ \\
\hline $\begin{array}{c}\text { Concrete } \\
\text { JI }\end{array}$ & - & 26 & - & - \\
JI-RC & - & 49 & - & - \\
JI-UFC & - & 98 & - & - \\
Rebar, JI & & & & \\
D10 & 71.3 & - & 471 & 651 \\
D19 & 286.5 & - & 514 & 652 \\
D25 & 506.7 & - & 487 & 669 \\
Rebar, JI-RC & & & & \\
D13 & 126.7 & - & 410 & 578 \\
D25 & 506.7 & - & 541 & 715 \\
\hline
\end{tabular}

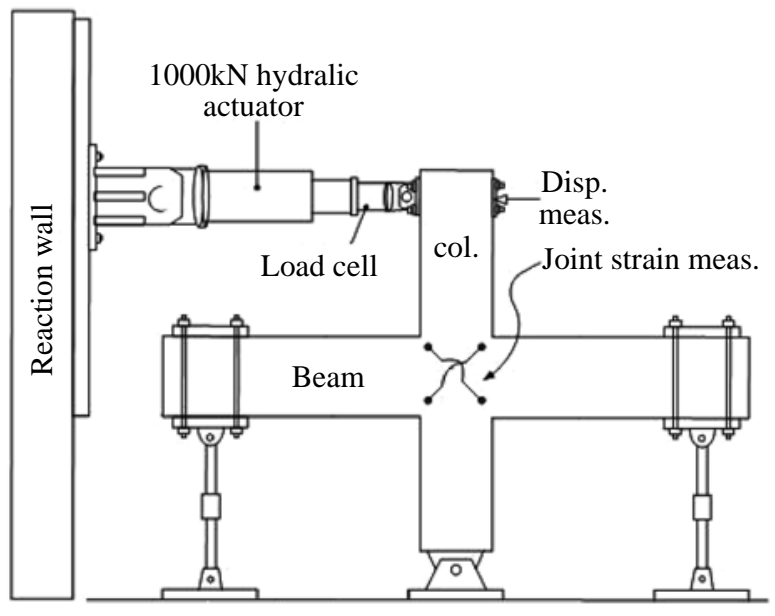

Fig. 3. Test set-up for testing frames.

column of the testing frame; see Figure 4. Besides the loading measurement, the frame displacement, diagonal joint strain, and rebar strain adjacent to the joint were all measured.

\section{EXPERIMENTAL RESULTS}

\section{Mechanical testing results of concrete materials}

Table 3 gives the basic mechanical properties, and the compressive and flexural tensile strengths, of NC, HSM, and UFC. A comparison of these strengths and the mechanical behaviors will be made below.

\section{(1) Abrasion test}

The abrasion coefficients for the different concrete specimens are presented in Table 4. After 500 and 
Table 3. Compressive and flexural strengths obtained from mechanical testing

\begin{tabular}{ccccccc}
\hline & \multicolumn{3}{c}{ Compressive strength (MPa) } & \multicolumn{3}{c}{ Flexural strength (MPa) } \\
\cline { 2 - 6 } & NC & HSM & UFC & NC & HSM & UFC \\
\hline 7 days & 22.3 & 46.1 & 170.7 & 4.7 & 4.3 & 16.3 \\
28 days & 34.1 & 65.8 & 181.6 & 5.9 & 5.3 & 19.7 \\
\hline
\end{tabular}

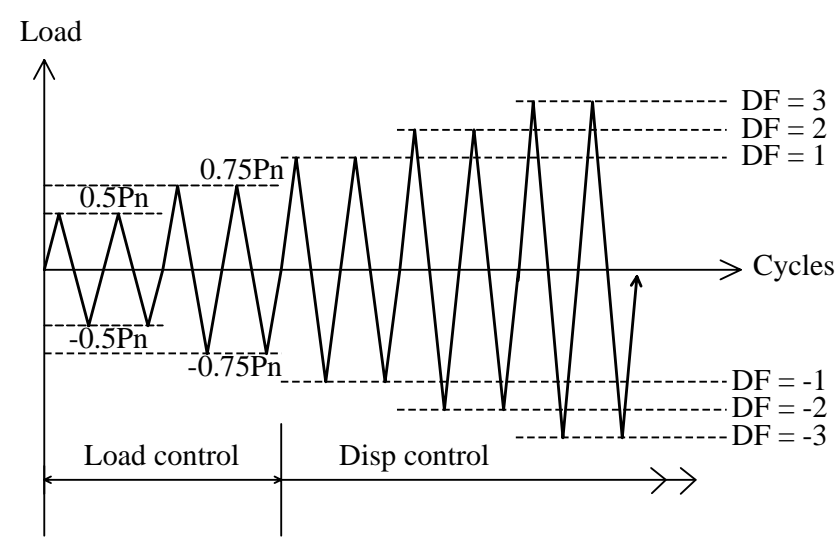

Fig. 4. Loading sequence.

1000 cycles of abrasion, the abrasion reduction by weight for the NC cylinders was $32 \%$ and $68 \%$, respectively, and for UFC it was $5 \%$ and $8 \%$, respectively. In other words the abrasion resistance of UFC is about 8 times higher than that of normal strength concrete, and about 4 times higher than that of HSM. Figure 5(a) shows the abrasion resistance of UFC in comparison with NC after 1000 cycles of abrasion.

\section{(2) Rebar pull-out test}

The changes in the steel bond strength of concrete cylinders with inserted steel bars after up to 1000 freezethaw cycles are given in Table 5. It can be seen that, in comparison with the UFC, the steel bond strength of NC
Table 4. Abrasion testing result - reduction rate in weight

\begin{tabular}{cccc}
\hline & NC & HSM & UFC \\
\hline $\begin{array}{c}\text { After 500-cycle } \\
\text { abrasion }\end{array}$ & $32 \%$ & $14 \%$ & $5 \%$ \\
$\begin{array}{c}\text { After 1000-cycle } \\
\text { abrasion }\end{array}$ & $68 \%$ & $33 \%$ & $8 \%$ \\
\hline
\end{tabular}

and HSM decreased significantly as the number of freeze-thaw cycles increased. NC and HSM failed by splitting after all the freeze-thaw cycles, while the UFC showed stronger bonding as the steel bar break off. Thus the UFC showed higher steel bond strength and better durability than either the NC or the HSM. Figure 5 (b) shows the different failure modes at the end of the test.

It should be noted that the length of the steel bar embedded in the $\mathrm{NC}$ was calculated according to design code ACI 318, as depicted in Table 5. The bond strength test results for NC, HSM and UFC, can be converted to the required length; see column 3 of Table 5. It is clear that for the UFC (with deformed steel reinforcement) developed only half the bonding length of normal reinforced concrete. This offers an advantage when a long anchorage length is needed for normal RC structures.

\section{(3) Slant shear strength and failure type}

The results, as seen in Table 6, show that the bond-

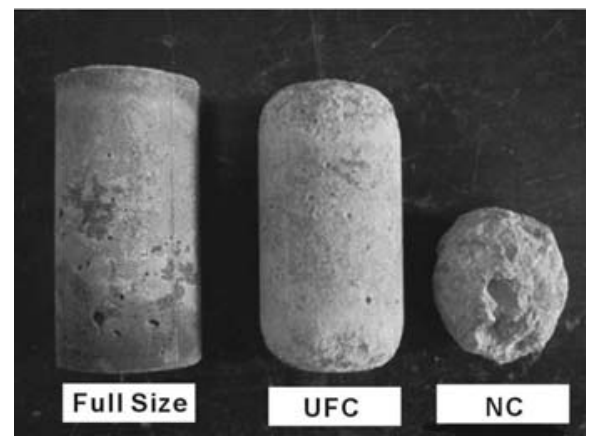

(a) Abrasion test

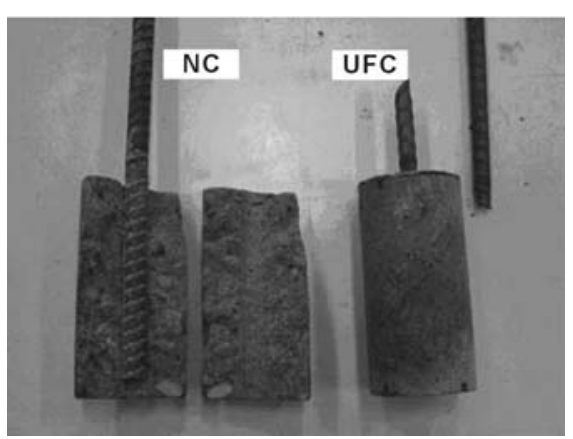

(b) Rebar pull-out test

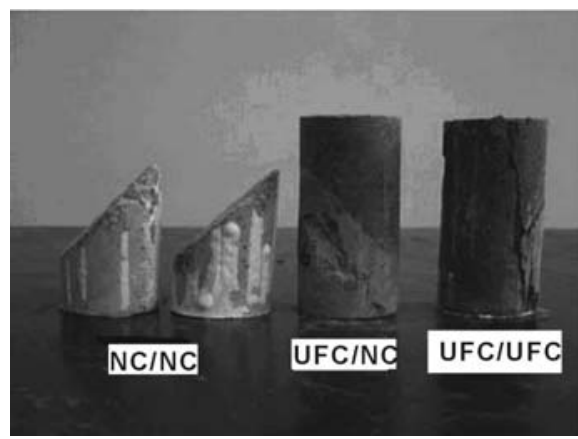

(c) Slant shear test

Fig. 5. Failure modes of different mechanical testing. 
Table 5. Steel bond strength and failure mode using different embedment materials

\begin{tabular}{|c|c|c|c|c|c|}
\hline & $\begin{array}{l}\text { 28-day, } \\
\text { bond strength } \\
\text { (MPa) }\end{array}$ & $\begin{array}{l}\text { Required } \\
\text { development } \\
\text { length } \\
(\mathrm{mm})\end{array}$ & $\begin{array}{c}28 \text { days+ } \\
\text { 300-cycle f\&t, } \\
\text { bond strength } \\
(\mathrm{MPa})\end{array}$ & $\begin{array}{c}28 \text { days+ } \\
600 \text {-cycle } f \& t, \\
\text { bond strength } \\
(\mathrm{MPa})\end{array}$ & $\begin{array}{c}28 \text { days+ } \\
\text { 1000-cycle f\&t, } \\
\text { bond strength } \\
(\mathrm{MPa})\end{array}$ \\
\hline \multirow{2}{*}{$\mathrm{NC}$} & 6.21 & $32 \mathrm{~d}_{\mathrm{b}}(\mathrm{Gr} .420)^{(\mathrm{a})}$ & 5.82 & 4.58 & 4.05 \\
\hline & Split failure & $21 \mathrm{~d}_{\mathrm{b}}(\mathrm{Gr} .280)$ & Split failure & Split failure & Split failure \\
\hline \multirow{2}{*}{ HSM } & 9.21 & $22 d_{b}(G r .420)^{(b)}$ & 8.84 & 8.05 & 7.05 \\
\hline & Split failure & $15 \mathrm{db}(\mathrm{Gr} .280)$ & Split failure & Split failure & Split failure \\
\hline \multirow{2}{*}{ UFC } & 12.70 & $16 d_{b}(G r .420)^{(b)}$ & 13.05 & 12.55 & 12.09 \\
\hline & Bond failure & $11 \mathrm{~d}_{\mathrm{b}}(\mathrm{Gr} .280)$ & Steel break off & Steel break off & Bond failure \\
\hline
\end{tabular}

Note:

1. Calculated from the development length specified in ACI 318M-02 [1], where NC f' $c=34 \mathrm{MPa}$ is adopted. $\mathrm{d}_{\mathrm{b}}$ is a diameter of deformed steel reinforcement. Gr. 420 represents steel fy $=420 \mathrm{MPa}$.

2. Compared with NC 28-day bond strengths to obtain the required development lengths of HSM and UFC.

Table 6. Slant shear strength and failure mode of different material combinations

\begin{tabular}{|c|c|c|c|c|c|}
\hline $\begin{array}{l}\text { Upper/Low } \\
\text { materials }\end{array}$ & $\begin{array}{l}28 \text { Days, } \\
\text { shear } \\
\text { strength, } \\
\text { t }(\mathrm{MPa})\end{array}$ & $\begin{array}{c}\text { Normalized } \\
\text { shear } \\
\text { strength } \\
\tau / \sqrt{f^{\prime}}\end{array}$ & $\begin{array}{c}28 \text { Days+ } \\
300 \text { Cycles, } \\
\text { shear strength } \\
(\mathrm{MPa})\end{array}$ & $\begin{array}{c}28 \text { Days+ } \\
600 \text { Cycles, } \\
\text { shear strength } \\
(\mathrm{MPa})\end{array}$ & $\begin{array}{c}28 \text { Days+ } \\
1000 \text { Cycles, } \\
\text { shear strength } \\
(\mathrm{MPa})\end{array}$ \\
\hline $\begin{array}{c}\mathrm{NC} / \mathrm{NC} \\
\mathrm{f}_{\mathrm{c}}=34.1\end{array}$ & $\begin{array}{c}12.4 \\
\text { Interface } \\
\text { failure }\end{array}$ & 2.12 & $\begin{array}{c}9.6 \\
\text { Interface failure }\end{array}$ & $\begin{array}{c}5.9 \\
\text { Interface failure }\end{array}$ & $\begin{array}{c}3.8 \\
\text { Interface failure }\end{array}$ \\
\hline $\begin{array}{l}\mathrm{HSM} / \mathrm{NC} \\
\mathrm{f}_{\mathrm{c}}=34.1\end{array}$ & $\begin{array}{c}12.6 \\
\text { Failure in } \\
\text { lower }\end{array}$ & 21.6 & $\begin{array}{c}12.4 \\
\text { Failure in lower }\end{array}$ & $\begin{array}{c}9.2 \\
\text { Interface Failure }\end{array}$ & $\begin{array}{c}7.0 \\
\text { Interface failure }\end{array}$ \\
\hline $\begin{array}{l}\mathrm{UFC} / \mathrm{NC} \\
\mathrm{f}^{\prime}{ }_{\mathrm{c}}=34.1\end{array}$ & $\begin{array}{c}13.7 \\
\text { Failure in } \\
\text { lower }\end{array}$ & 2.35 & $\begin{array}{c}12.8 \\
\text { Failure in lower }\end{array}$ & $\begin{array}{l}11.3 \\
\text { Failure in lower }\end{array}$ & $\begin{array}{c}9.1 \\
\text { Interface failure }\end{array}$ \\
\hline $\begin{array}{l}\mathrm{UFC} / \mathrm{UFC} \\
\mathrm{f}_{\mathrm{c}}=181.6\end{array}$ & $\begin{array}{c}59.6 \\
\text { Failure in } \\
\text { lower and } \\
\text { upper }\end{array}$ & $\begin{array}{l}58.9 \\
4.42\end{array}$ & $\begin{array}{c}59.0 \\
\text { Failure in lower } \\
\text { and upper }\end{array}$ & $\begin{array}{c}57.6 \\
\text { Failure in lower } \\
\text { and upper }\end{array}$ & $\begin{array}{l}\text { Failure in lower } \\
\text { and uper }\end{array}$ \\
\hline
\end{tabular}

ing strength between two substrates of NC/NC, HSM/ $\mathrm{NC}$ and UFC/NC decreased by a significantly higher amount after the freeze-thaw process than did that of UFC/UFC. In particular the NC/NC specimens showed severe deterioration after 600 to 1000 cycles.

There were three different failure modes shown during the slant shear test. For the NC/NC specimens the failure mode was interface failure, whereas for the UFC/UFC specimens, failure occurred between the lower and upper substrates. The HSM/NC and UFC/NC specimens were subject to both interface failure and substrate failure, because the NC and HSM specimens had rela- tively lower concrete shear strength than that of the UFC specimens. Figure 5(c) shows the different failure modes during the slant shear test. It can be concluded that UFC would be a suitable repair or construction material, because not only does it have higher shear resistance, it also has greater durability. The normalized shear strength results shown in column 3 of Table 6 indicate that UFC has twice the shear resistance as normal concrete. This means that structural elements that are subjected to high shear could be strengthened with UFC, for example the rehabilitation of beamcolumn joints described below. 


\section{Beam-column joint frame testing results}

According to the results presented above, UFC performs well in terms of its compressive, shear, and reinforcing bond strengths, which would mean that it has merit as a strengthening material for beam-column joint cores. In addition to the above unit JI-UFC, the prototype unit JI and the $\mathrm{NC}$-encased unit JI-RC was tested for comparison.

\section{(1) Overall behavior}

Figure 6 shows the relationship of the overall frame displacement to cyclic loading for the three units. As described in the testing program, the as-built JI unit presented one main deficiency in the joint, where there was no joint shear reinforcement. The expected damage to the joint part can be seen in Figure 6(a). The displacement ductility $\mu_{\mathrm{d}}$ used for evaluation of the ductile behavior of the frame is defined as the ratio of measured displacement to yield displacement which is calculated from the theoretical flexural strength of the beam. The strength of the JI frame degraded as it had earlier in the linear stage, about when the cycle to displacement ductility was $\mu_{\mathrm{d}}=1.5$. Meanwhile, the strength did not reach the desired value corresponding to the beam flexural strength. The failure mode of unit JI represents the non-ductile behavior that can be expected of Taiwan low-rise buildings.

The RC jacketed JI-RC unit represents the traditional widely accepted retrofitting scheme used in Taiwan. It is particularly used for RC frames with beam-column joint deficiencies. The advantage of this method is that RC jackets can be used to easily repair substandard joints, without any need for skilled labor, which naturally reduces the cost of the structural strengthening. Figure 6(b) shows feasible seismicresisting performance. The cracking had found in the beam ends adjacent to the column face, which formed as beam hinging action. The entire frame reached its desired strength and the strength lasted until displacement ductility $\mu_{\mathrm{d}}=5$. That is, RC jacketing for the seismic-strengthening of a deficient frame with nonductile joints is effective. However, the conventional retrofitting method has the disadvantages of extra requirements for strengthening foundations and architectural problems involving space shortage, and of passing-over the property lines for circumferential frames.

UFC replacement-strengthening for non-ductile joints may be a new solution for the disadvantages of the JI-RC unit mentioned above. Although the JI-UFC method is currently used for structural repairs, UFC could also be adopted for new element construction. Figures 6(b) and (c) show similar hysterias loops for both units JI-RC and JI-UFC. However, the strengthened frame JI-UFC shows better seismic performance in terms of strength and ductility. Beam hinging in JI-UFC has been exerted at the end of the beams but the damage from the beam ends and diagonal cracks at the joints are not as serious as with JI-RC. This means that the seismic resistance is better than that of the RC jacketed unit.

\section{(2) Discussion on joint shear strength}

To further study the behavior of the shear resistance of different concrete materials used for joint shear strengthening, the relationship between the joint shear stress and strain, attained from measurement of the joint area, is discussed; see Figure 7. It is obvious that the initial shear stiffness (the so-called shear modulus) is similar for all three units but the highest joint shear strength is different.

In the comparison of JI and JI-UFC depicted in Figure 7, it can be seen that the joint shear failure mode of the prototype JI unit had the maximum joint shear strength of 5.59 MPa (see also Table 7), whereas the strengthened unit JI-UFC was subject to the ductile failure mode when the imposed joint shear strength was as high as $7.09 \mathrm{MPa}$. The joint shear resisting areas were the same, but the shear strength of UFC, sustained at the end of testing, was different from $\mathrm{NC}$, which is not a limited value. The shear modulus for UFC joint was linear all the way up to failure. For unit JI, the nonlinearity in joint shear appeared at the post cyclic excursions.

The joint shear strength is normalized with the square root of the concrete strength; see the last column of Table 7. The imposed maximum shear strength for JI unit is beyond the limited value depicted in Eq. (1) [6], however, that for JI-UFC unit is lower than the limited value. This indicates that, by means of the comparison between measured and limited values, JI unit could fail in joint shear as a brittle manner whereas JI-UFC unit would damage in beam flexure as a ductile behavior. The failure mode of JI-UFC was changed from brittle to ductile behavior because of joint core replaced by UFC. Meanwhile, It can be seen in Figure 7 that JI-UFC showed stiffer shear resistance than the RC jacketed unit JI-RC. Although the NC jacketing of the JI-RC unit caused the failure mode to become a ductile one, the shear deformation, at the maximum imposed shear, became larger after JI-RC was subjected to a few loading cycles. The implication is that UFC would be a better material than $\mathrm{NC}$ jacketing for strengthening non-ductile beam-column joints.

It is believed the shear capacity of RC jacketed JI$\mathrm{RC}$ would be similar to that of the prototype JI, as 


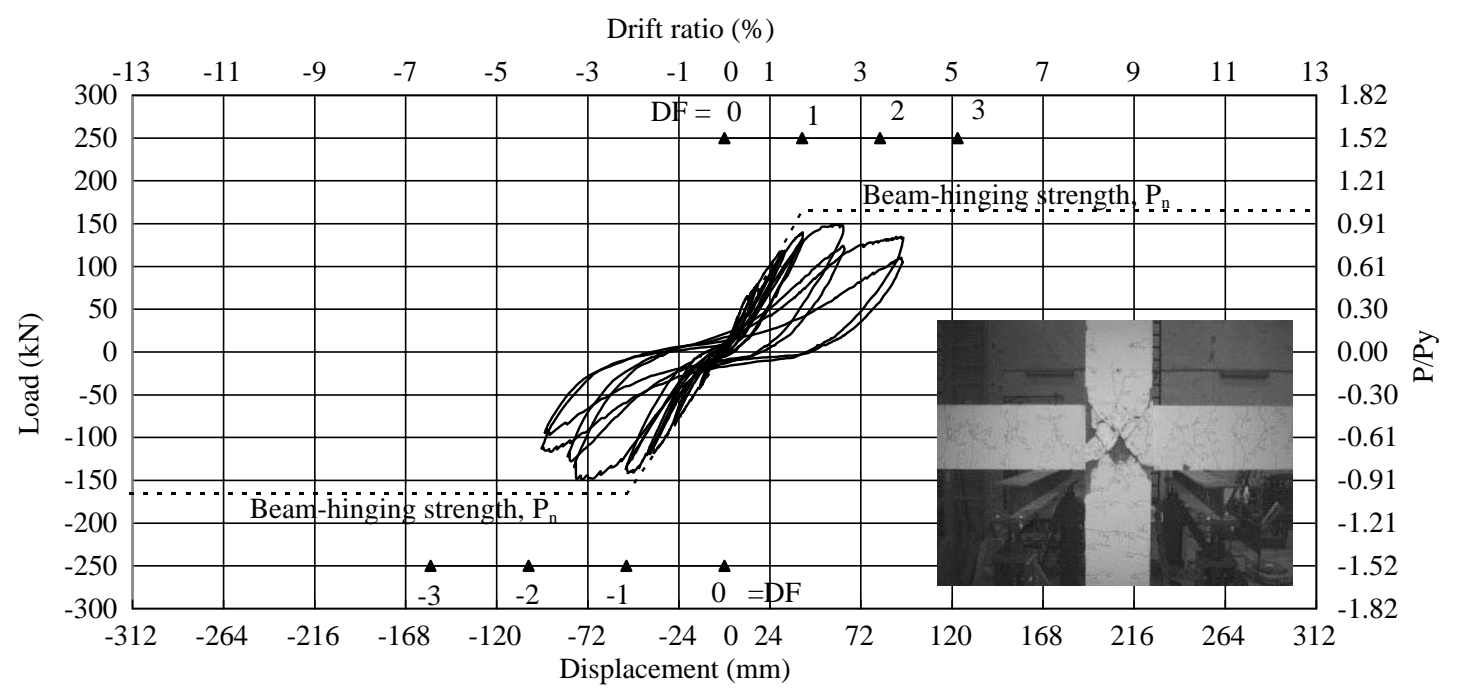

(a) as-built, JI

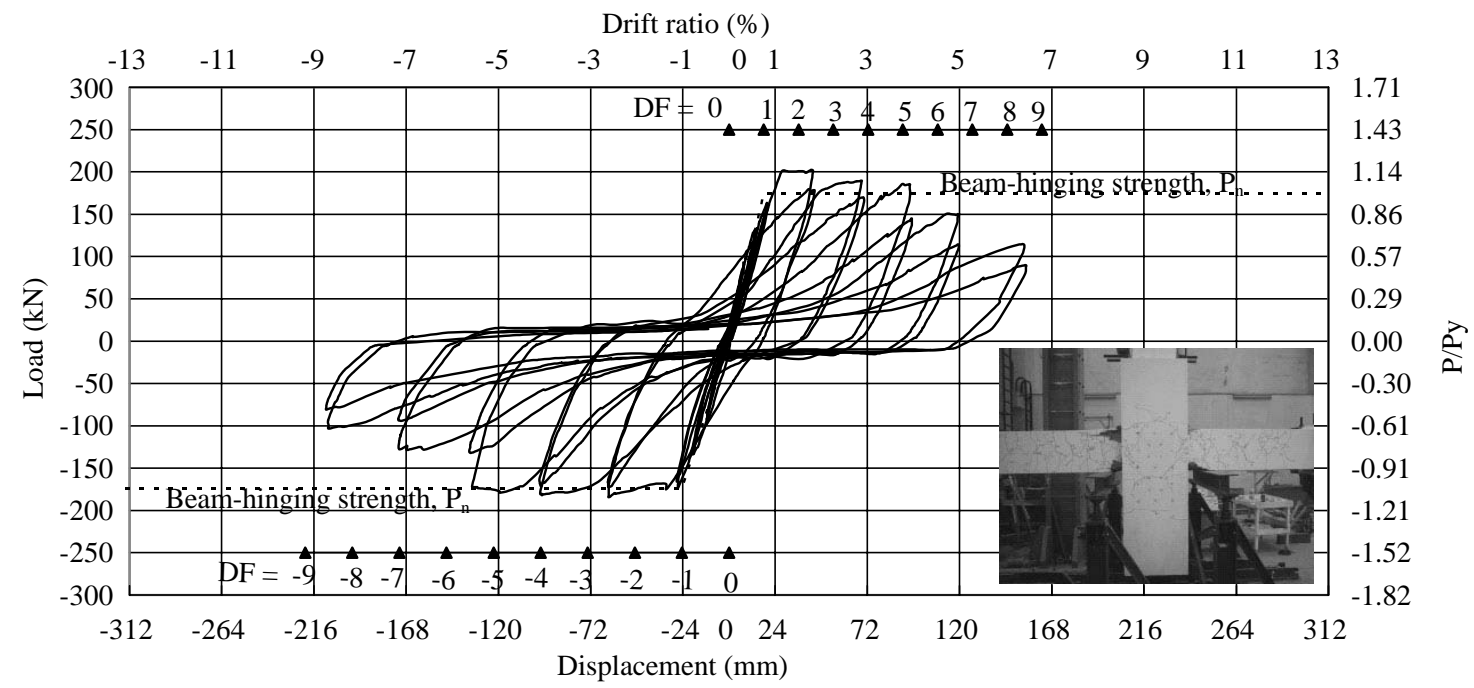

(b) RC jacketing, JI-RC

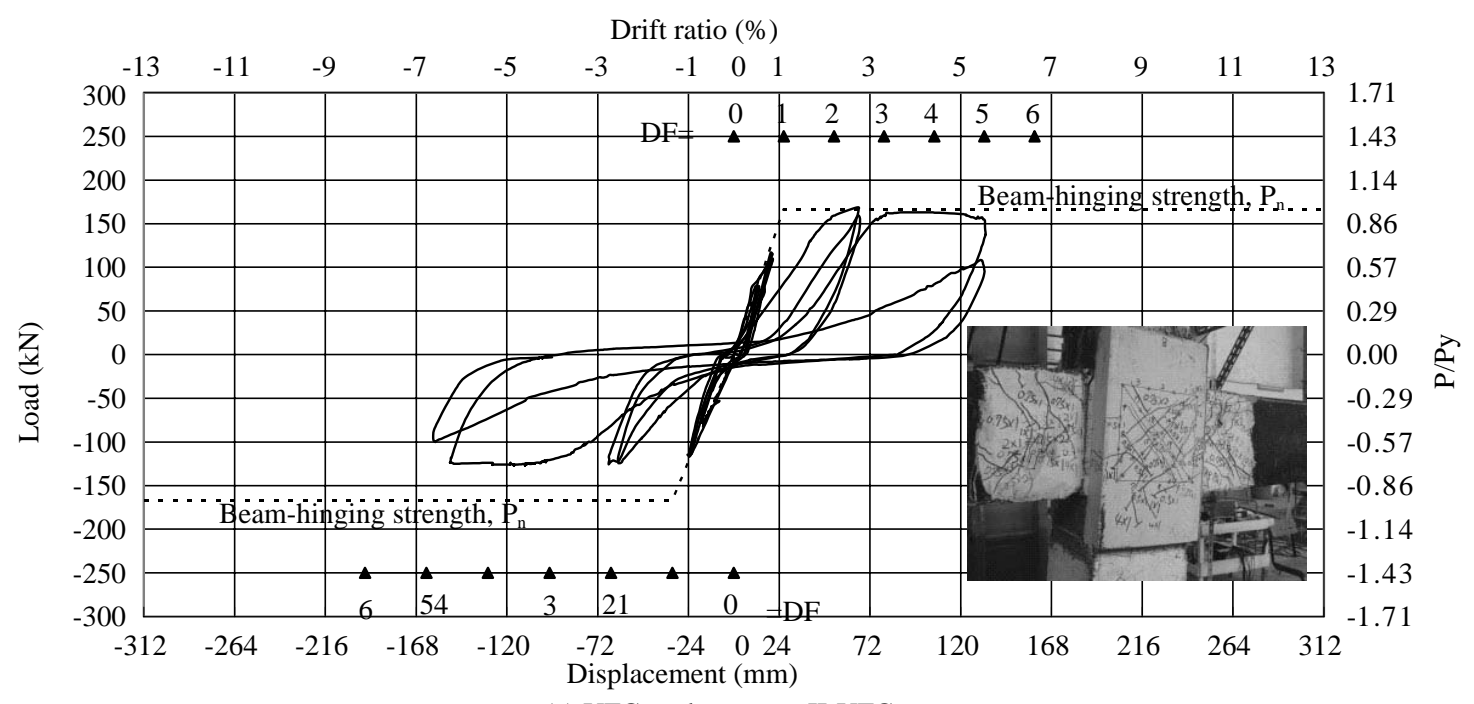

(c) UFC-replacement, JI-UFC

Fig. 6. Hysterias loop of beam-column joints. 
Table 7. Measured shear strengths imposed to beam-column joints for three tested units

\begin{tabular}{|c|c|c|c|c|c|}
\hline Unit & $\begin{array}{c}(1) \\
\text { imposed } \\
\text { max. joint } \\
\text { shear } \\
(\mathrm{kN})\end{array}$ & $\begin{array}{c}(2) \\
\text { effect joint } \\
\text { area } \\
\left(\mathrm{mm}^{2}\right)\end{array}$ & $\begin{array}{c}(3) \\
f_{c j}^{\prime} \\
\text { concrete strength } \\
\text { in joint core } \\
(\mathrm{MPa})\end{array}$ & $\begin{array}{c}(4)=(1) /(2) \\
v_{j h} \\
\text { imposed max. } \\
\text { joint shear stress } \\
(\mathrm{MPa})\end{array}$ & $\begin{array}{l}(5)=(4) /(3) \\
v_{j h} / \sqrt{f^{\prime}{ }_{c j}}\end{array}$ \\
\hline JI & 894 & 160000 & 26 & 5.59 & 1.10 \\
\hline JI-RC & 1167 & 360000 & $38^{*}$ & 3.24 & 0.53 \\
\hline JI-UFC & 1135 & 160000 & 98 & 7.09 & 0.72 \\
\hline
\end{tabular}

* Take an average value for different concrete strengths in joint core.

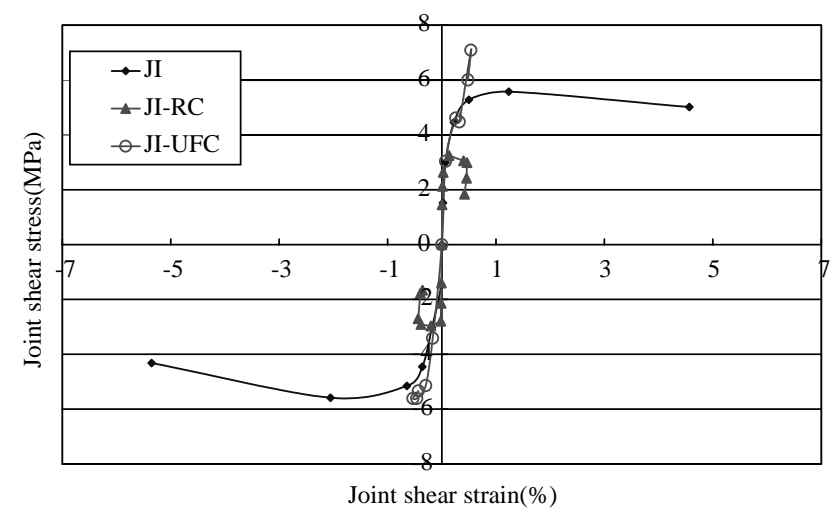

Fig. 7. Joint shear stress and strain for test units.

presented in Eq. (1), mainly due to the same NC materials being used in the two types of joints. Although the joint core with UFC has a higher shear modulus than that with normal concrete and the behavior of linearity in shear up to failure, so far the UFC joint shear strength could be simply evaluated by equation (1), similar to normal concrete beam-column joints.

$$
v_{j}=1.0 \sqrt{f_{c j}^{\prime}}(\mathrm{MPa}) \text { for interior joints without }
$$
transverse hoops [6]

where $v_{j}$ is the shear capacity for the NC and UFC beam-column joints, and $f_{c j}^{\prime}$ is the strength of concrete in the joint core.

\section{CONCLUSIONS}

The main findings from this study can be summarized as follows:

1. Ultra-high strength steel fiber reinforced concrete (UFC) displays excellent potential in terms of superior abrasion resistance and compressive, flexural, rebar bonding, and shear resisting strengths. The length of rebar required in UFC is approximately half that required in NC. Similar to the steel bonding strength, the slant shear strength of UFC (normalized with the square root of the compressive strength of the concrete) is twice that of NC.

2. The good durability of UFC is also shown by its high resistance to freeze-thaw reactions and lower weight loss during abrasion testing.

3. NC column-jacketing and UFC joint-replacement can be adopted to improve the poor seismic behavior of moment-resisting frames without transverse reinforcement at the beam-column joints. Both the retrofitted frames show better seismic performance than the asbuilt frame. However, the shear resistance of the infilled UFC joint is excellent, better than that of the joint encased with the NC jacket.

4. From the frame test results it can be seen that the NCprototype or $\mathrm{NC}$-jacketed interior beam-column joint (in which there was no transverse reinforcement) was able to withstand a nominal joint horizontal shear stress of $1.0 \sqrt{f_{c j}^{\prime}}$ MPa. The nominal horizontal shear stress proposed for the UFC-infilled joint, (on the conservative side) was similar to $\mathrm{NC}$ joint, which is $1.0 \sqrt{f_{c j}^{\prime}} \mathrm{MPa}$. More experimental study using fullsize beam-column joints infilled with UFC (for both strengthening and new construction purposes) is necessary.

\section{ACKNOWLEDGEMENT}

The authors would like to thank the National Science Council of Taiwan for the financial support under the grant NSC 93-2211-E-008-019.

\section{REFERENCES}

1. ACI Committee 318, Building Code Requirements for Structural Concrete (ACI 318M-02) and Commentary (ACI 318RM-02), American Concrete Institute (2002).

2. Alaee, F.J., "Retrofitting of Concrete Structures using High Performance Fiber Reinforced Cementitious 
Composite (HPFRCC)," Ph.D. Thesis, University of Wales, Cardiff (2001).

3. Bonneau, O., Lachemi, M., Dallaire, E., Dugat, J., and Aitcin, P.C., "Mechanical Properties and Durability of Two Industrial Reactive Powder Concretes," ACI Materials Journal, Vol. 94, No. 4, pp. 286-290 (1997).

4. Emmons, P.H., Concrete Repair and Maintenance Illustrated: Problem Analysis, Repair Strategy and Techniques, R. S. Means Company, Inc., Kingston, MA (1993).

5. Green, M.K., Bisby, L.A., Beaudoin, Y., and Labossière, P., "Effect of Freeze-thaw Cycles on the Bond Durability between Fibre Reinforced Polymer Plate Reinforcement and Concrete," Journal of Civil Engineering, NRC Canada, Vol. 27, pp. 949-959 (2000).

6. Hakuto, S., Park, R., and Tanaka, H., "Seismic Load Tests on Interior and Exterior Beam-Column Joints with Substandard Reinforcing Details," ACI Structural Journal, Vol. 97, No. 1, pp. 11- 25 (2000).

7. Lee, M.G., and Wang, Y.C., "A Preliminary Study of
Strengthening Concrete Members using Reactive Powder Concrete," Journal of Chinese Civil and Hydraulic Engineering, Vol. 16, No. 4, pp. $715-721$ (2004).

8. Neville, A.M., Properties of Concrete, John Wiley \& Sons, Inc., New York (1995).

9. Roux, N., Andrade, C., and Sanjuan, M., "Experimental Study of Durability of Reactive Powder Concrete," Journal of Materials in Civil Engineering, Vol. 8, No. 1, pp. 12-20 (1996).

10. Wang, Y.C., Kao, C.J., and Yang, C.T., "Investigation on Shear Strength Enhancement of Beam-Column Joint Retrofitted with RC Jacketing," Journal of Chinese Civil and Hydraulic Engineering, Vol. 15, No. 3, pp. 521-530 (2003).

11. Wang, Y.C., Lee, M.G., and Ho, W.C., "An Investigation of Bond Slip in the Interface Between New and Old Concrete of Beam-Column Joints Retrofitted with RC Jacketing," Journal of Chinese Civil and Hydraulic Engineering, Vol. 17, No. 1, pp. 73-80 (2005). 